\title{
Flowering Dynamics in Alfalfa (Medicago sativa L.) Based on Heat Units
}

\author{
Bolaños-Aguilar Eduardo Daniel ${ }^{{ }^{*}}$, Christian Huyghe ${ }^{2}$, Enríquez-Quiroz Javier Francisco ${ }^{3}$ \\ ${ }^{1}$ Instituto Nacional de Investigaciones Forestales Agrícolas y Pecuarias. Campo Experimental \\ Huimanguillo. Huimanguillo, Tabasco, México. CP. 86600. ${ }^{2}$ Institut National de la Recherche \\ Agronomique. Lusignan, France. CP. 86600. ${ }^{3}$ Instituto Nacional de Investigaciones Forestales \\ Agrícolas y Pecuarias. Campo Experimental "La Posta". Paso del Toro, Veracruz, México. CP. 94277. \\ *Corresponding Author: bolanos.eduardo@inifap.gob.mx
}

\begin{abstract}
Objective: To describe the sequential pattern of reproductive development of Medicago sativa L. (flowering dynamic) using the relation between principal floral stem nodes and accumulated growing degree day (GDD) in different environmental conditions, and to determine the use of this relationship as a predictor of the seed harvesting date.
\end{abstract}

Design/Methodology/Approach: It was carried out in random blocks and factorial arrangement of $2 \times 5$, with two repetitions. Each repetition was made up of 30 plants.

Results: The flowering dynamic followed the same pattern between varieties, with a linear relation between GDD and number of floral nodes. The year A0 was different from the years A1 and A2. Therefore, A1 with cutting, and A2 with and without cutting presented less GDD during the flowering stage. In contrast, A0 showed more GDD during this period. In the different environmental conditions, the linear curves of flowering dynamic turned erratic after the tenth floral node (300 GDD) due to a low rate of plants with more than 10 floral nodes along the principal stem.

Study Limitations/Implications: It is necessary to have a meteorological station near the alfalfa seed production site, in order to specify the GDD required for predicting the correct moment to harvest seeds.

Findings/Conclusions: The reproductive development of $M$. sativa presents a linear relation between the number of floral nodes and GDD, which allows the prediction of the optimal seed harvesting date, in any environmental condition present.

Key words: Growth, accumulated growing degree days, flowering.

\section{INTRODUCTION}

A

Ifalfa (Medicago sativa L.) develops a group of erect thin primary stems of up to one meter in height with branching. Each stem is composed of several vegetative and floral nodes. This branching pattern gives rise to a certain growth habit with indefinite sequential flowering between the different nodes along each stem (Lesins and Lesins, 1979). The information available describing the pattern of the flowering dynamic between floral nodes along alfalfa stems is limited. This information is important in order to understand and predict

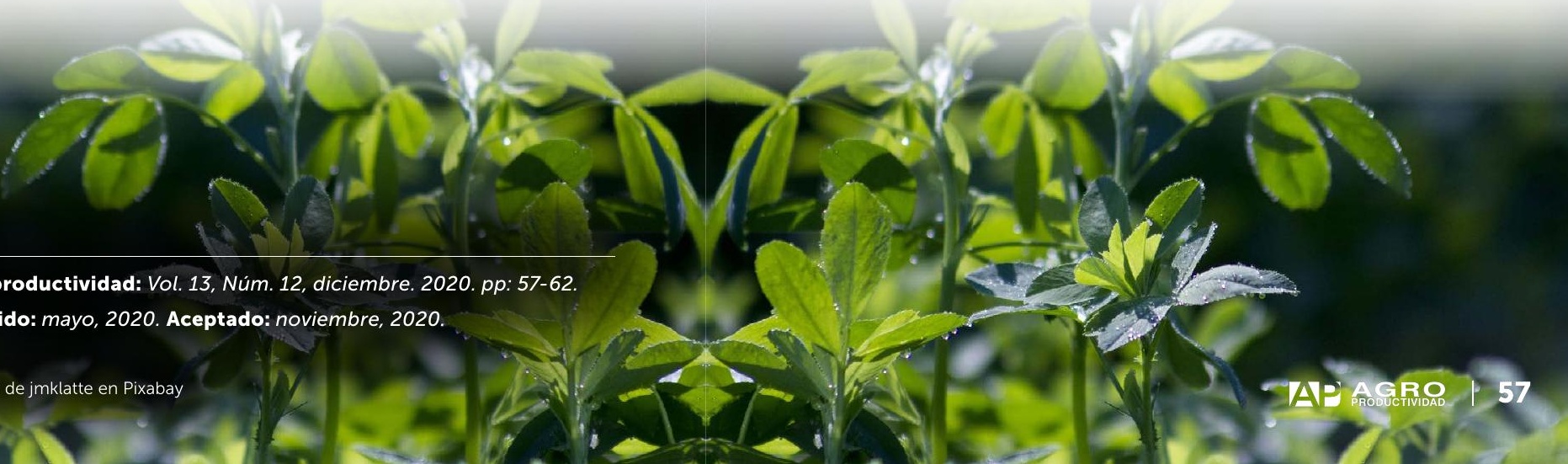


the variations of seed production and its distribution along the canopy.

The flowering dynamic has been described in other Fabaceae species to understand the variations in grain yield between plants, such as in soy (Glycine max L.) (Nico et al., 2016), fava bean (Vicia faba L.) (Daur et al., 2011), and lupin (Lupinus angustifolius L.) (LagunesEspinoza et al., 2000). In alfalfa it has been shown that the competition for nutrients between densely sowed plants increases and the rate of flowering decreases (Baldissera et al., 2014). This allows assuming that the selection of fodders normally carried out in isolated plants could generate erroneous information on the flowering dynamic and seed production, since there is not high competition for nutrients between plants, as seen in dense canopies which are the normal conditions of fodder growth.

Taking into account that the environmental temperature is correlated to plant development, the concept of accumulated growing degree days (GDD) could be used as a tool to predict the development of flowering toward a specific phenological stage (Krishna-Jagadish et al., 2016). In order to achieve this, it is important to know the basal temperature (Tb) of the crop of interest. The $\mathrm{Tb}$ is that which minimizes the variability of the required GDD necessary for a plant to achieve a specific phenological stage (Jungers et al, 2016). Years ago, the minimal temperature for the growth of alfalfa leaves was considered to be $5{ }^{\circ} \mathrm{C}$ (Sanderson et al., 1994). A basal temperature of $5{ }^{\circ} \mathrm{C}$ has been more frequently used in the development of prediction equations in alfalfa seed production for all stages of development (Bolaños-Aguilar and Huyghe, 2005). The objective was to understand the sequential pattern of reproductive development between the different floral nodes along the primary stem, in function of the accumulated growing degree days (GDD) with the aim of determining if that pattern varies with the environmental conditions of crop growth and with the variety, in order to know the feasibility of predicting the optimal date of seed harvesting associated with the relation between reproductive development and GDD.

\section{MATERIALS AND METHODS}

The study was carried out in field conditions during two years in the Center of Genetic Improvement of Forage Plants in Lusignan $\left(46.26^{\circ} \mathrm{N} ; 0.07^{\circ} \mathrm{E}\right)$ of the National Institute of Agricultural Research (INRA) in France. European and Magali varieties of alfalfa were studied, the former known for its resistance to cold and lodging and the latter for adapting better to Mediterranean climate and less resistance to lodging. In both varieties the sowing density was $10 \mathrm{~kg} \mathrm{ha}^{-1}$, established in a design of random blocks in factorial arrangement of $2 \times 5$ with two repetitions. Each repetition had 30 plants. The area of each plot or repetition was $18.75 \mathrm{~m}^{2}$, formed by four lines of $7.5 \mathrm{~m}$ long by $0.41 \mathrm{~m}$ between lines. For this study, central lines were used, eliminating the two external lines in order to avoid the border effect. Sowing was done in each line with the chorrillo technique. The present study was carried out in five different environmental conditions presented in Table 1.

For the creation of these environmental conditions, plants were evaluated in sowing year (AO), plants cut one year after sowing (A1 with cut), plants cut two years after sowing (A2 with cut), and plans without cutting two years after sowing (A2 without cut). Cutting was done at a height of $6 \mathrm{~cm}$ above ground level, beginning evaluations at the beginning of the month of May. Climate data were obtained from the same Research Center for every year. To record flowering dynamics, 30 primary stems (one per plant) were randomly selected by variety and repetition before the beginning of flowering.

The distance between the stems was approximately 0.20 $m$, to ensure that they did not belong to the same plant. The start of flowering of each variety was registered the moment when $20 \%$ of the stems selected presented one open flower in the inflorescence inserted on the first floral node of the primary stem of each plant selected. A node was considered floral when it developed at least one completely open flower (anthesis) in its inflorescence. As

\begin{tabular}{|c|c|c|}
\hline \multirow[b]{2}{*}{ Variety } & \multicolumn{2}{|c|}{ Treatments } \\
\hline & $\begin{array}{c}\text { Environmental } \\
\text { condition }\end{array}$ & $\begin{array}{l}\text { Sowing date of } \\
\text { treatments }\end{array}$ \\
\hline Europa & $\begin{array}{l}\text { Y0-1997 } \\
\text { Y0-1998 } \\
\text { Y1 with cutting } \\
\text { Y2 with cutting } \\
\text { Y2 without cutting }\end{array}$ & $\begin{array}{l}\text { April } 1997 \\
\text { April } 1998 \\
\text { April } 1997 \\
\text { April } 1995 \\
\text { April } 1995\end{array}$ \\
\hline Magali & $\begin{array}{l}\text { Y0-1997 } \\
\text { Y0-1998 } \\
\text { Y1 with cutting } \\
\text { Y2 with cutting } \\
\text { Y2 without cutting }\end{array}$ & $\begin{array}{l}\text { April } 1997 \\
\text { April } 1998 \\
\text { April } 1997 \\
\text { April } 1995 \\
\text { April } 1995\end{array}$ \\
\hline
\end{tabular}

A0: Sowing year; 1997 and 1998: Consecutive sowing years; A1: Regrowth year of sowing from 1997; A2: With cutting and without cutting: Regrowth year of sowing from 1995. 
of the first open flower from the first floral node, every third day the opening of the first flower of each floral node along the primary stem was registered and tagged.

The progress of the number of alfalfa floral nodes was described in linear functions based on accumulated growing degree days (GDD) from the beginning of flowering until seed maturity (period of reproductive development). With this data the average number of floral nodes was calculated for each treatment. The duration of the reproductive period was based on the sum of GDD. The GDD were calculated by

$$
G D D=\sum(T-T b)
$$

where $T$ is the average daily temperature (maximum temperature + minimum temperature/2), and $T b$ is the baseline temperature, established at $5{ }^{\circ} \mathrm{C}$ for alfalfa (Sharrat et al., 1989). This Tb of $5{ }^{\circ} \mathrm{C}$ was applied in all of the environments evaluated.

The linear regressions for the flowering dynamics from their start until seed maturity, for all treatments, were

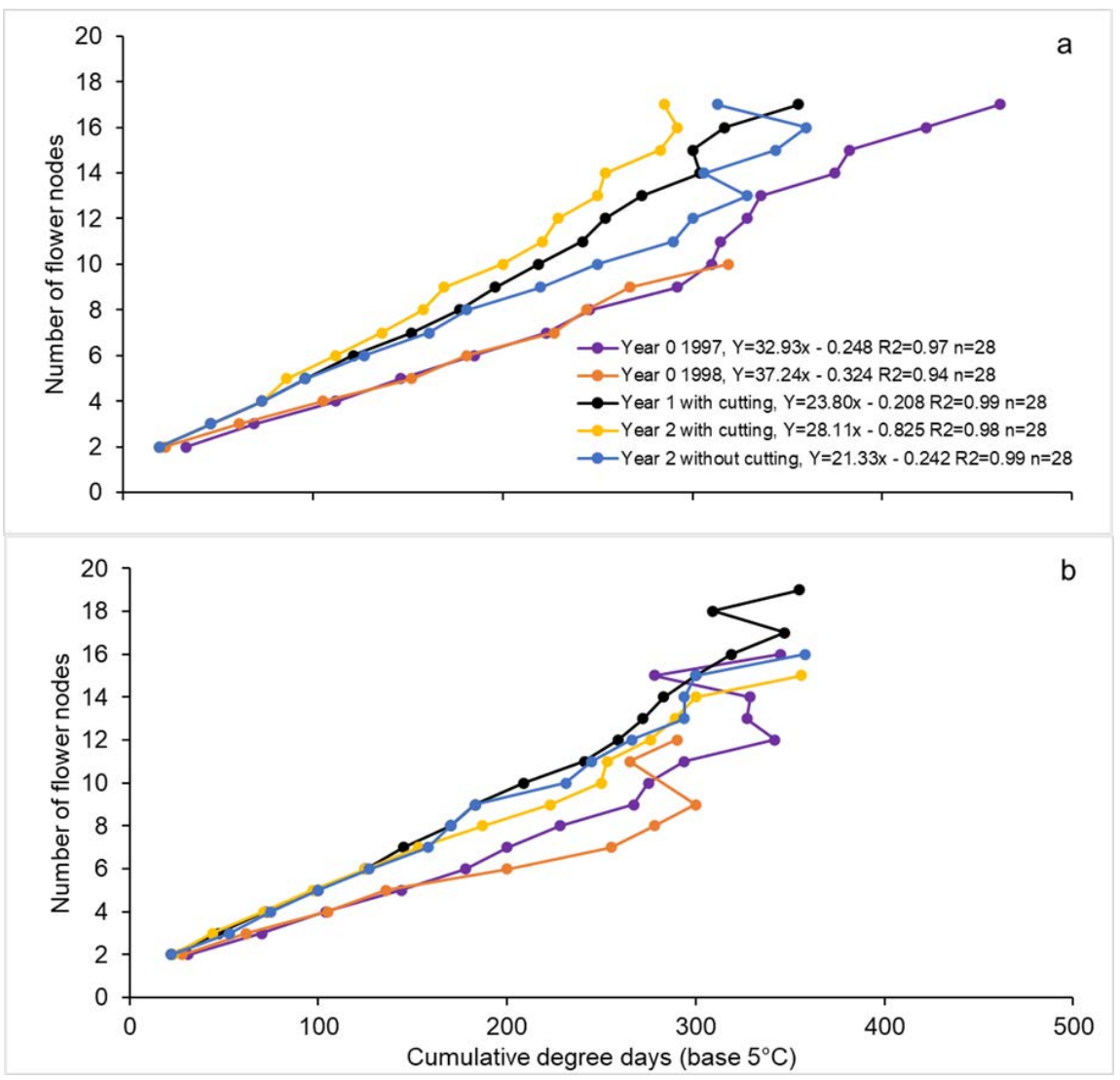

Figure 1. Relation between the number of flower nodes and accumulated growing degree days (GDD) in European (a) and Magali (b) varieties of Medicago sativa L., in different environmental conditions. done using the REG procedure from SAS (SAS, 2010). The slope of each regression curve was used in order to estimate the flowering dynamics along the primary stem expressed as the GDD necessary for the sequential flowering of floral nodes on the primary stem. The regression model was

$$
y=a+b x
$$

where $y=$ number of floral nodes, $a=$ regression constant, $x=$ accumulated growing degree days (Tb $=5$ ${ }^{\circ} \mathrm{C}$ ), and $b=$ regression slope.

\section{RESULTS AND DISCUSSION}

The pattern of flowering dynamics (relation between the number of flower nodes and GDD) along the primary stem for the European and Magali varieties in each environmental condition is represented in Figures $1 a$ and $b$, respectively. It was observed that in both varieties the flowering dynamics follow the same linear pattern, increasing the number of floral nodes with an increase in the GDD. This linear relation between the number of open flowers and the GDD was also observed in field conditions in bean cultivation (Jenni et al., 2000; Kakon et al., 2019). The flowering dynamics varied between different environmental conditions (Table 2).

Independently of the variety, the flowering dynamics was slower in $\mathrm{AO}$ than in $A 1$ and $A 2$, because an increased number of GDD were required in $\mathrm{AO}$ for sequential flowering of floral nodes in the primary stem. Table 2 also shows that between $\mathrm{A} 1$ and $\mathrm{A} 2$ without cutting there was no significant difference in flowering dynamics. The lower flowering dynamics seen in $\mathrm{AO}$ could be consequence of the differences of source-demand relationships in the plant. The former explanation is based on Khaiti and Lemaire (1992), who demonstrated that there is a more efficient use of solar radiation in the formation of biomass in alfalfa for regrowth years ( $\mathrm{A} 1$ and $\mathrm{A} 2$ ) than for the sowing year (AO). This is explained by the higher leaf area index and by higher stem density per plant in regrowth years. This was corroborated by Bolaños-Aguilar and Huyghe (2005) and Nico et al. (2016) in 
Table 2. Environmental condition, number of flower nodes and flowering dynamics in accumulated growing degree days (GDD) with $5{ }^{\circ} \mathrm{C}$ basal temperature for two varieties of Medicago sativa L.

\begin{tabular}{c|l|c|c}
\hline \multirow{2}{*}{ Varieties } & \multicolumn{1}{|c|}{$\begin{array}{c}\text { Condition } \\
\text { environmental }\end{array}$} & $\begin{array}{c}\text { Average number of } \\
\text { flower nodes }^{1}\end{array}$ & $\begin{array}{c}\text { Flowering dinamics } \\
\text { in CDD }\end{array}$ \\
\hline \multirow{5}{*}{ Europa } & Y0-1997 & $5.88 \mathrm{a}$ & $32.93 \mathrm{c}$ \\
& Y0-1998 & $5.64 \mathrm{a}$ & $37.24 \mathrm{~d}$ \\
& Y1 with cutting & $4.23 \mathrm{~b}$ & $23.80 \mathrm{a}$ \\
& Y2 without cutting & $4.53 \mathrm{ab}$ & $21.33 \mathrm{a}$ \\
& Y2 with cutting & $6.71 \mathrm{a}$ & $28.11 \mathrm{~b}$ \\
\hline \multirow{5}{*}{ Magali } & Y0-1997 & $6.53 \mathrm{a}$ & $30.41 \mathrm{c}$ \\
& Y0-1998 & $6.29 \mathrm{a}$ & $34.81 \mathrm{~d}$ \\
& Y1 with cutting & $6.26 \mathrm{a}$ & $22.52 \mathrm{a}$ \\
& Y2 withput cutting & $6.21 \mathrm{a}$ & $24.67 \mathrm{ab}$ \\
& Y2 with cutting & $6.08 \mathrm{a}$ & $26.39 \mathrm{~b}$ \\
\hline
\end{tabular}

Means with the same letters between lines in the variety are not statistically different $(P>0.05)$. A0, A1, A2; sowing year and two years after regrowth, respectively. ${ }^{1}$ Each average is the result of 60 registered products of two repetitions with 30 stems each. conditions evaluated, even though the original environment was different for each of them. However, there were differences $(p<0.05)$ in the flowering dynamics between growing environmental conditions for each variety. Thus, the GDD required to pass from one floral node to the other in the European variety was 21.33 to 37.24 GDD, which corresponded to $\mathrm{A} 2$ conditions without cutting and to A0-1998, respectively, and for the Magali variety of 22.52 to 34.81 GDD with regard to the A1 conditions without cutting and A0-1998. Considering that between the two varieties there was similar flowering dynamics in any of the environmental conditions evaluated, the GDD required alfalfa, when observing that at higher leaf area and number of stems induces a higher accumulation of dry matter at the time of seed harvesting, with higher seed production seen in regrowth years.

Similarly, in another study by Bolaños-Aguilar et al. (2002) on alfalfa seed production carried out in 12 different environmental conditions, they observed that lower seed productions took place in the sowing year (A0), than in subsequent growing periods showing a genetic correlation of 0.79 between seed production and dry matter accumulation present at the time of seed harvesting. These results were explained as a consequence of lower dry matter production in $\mathrm{AO}$, which was subsequently seen in other studies (Brown et al., 2006; Otero and Castro, 2019).

The European and Magali alfalfa varieties showed similar flowering dynamics in the different environmental for seeds to reach maturity and be ready for harvesting was calculated by combining the results of the two varieties (Table 3).

The A2 conditions with and without cutting had a total of GDD during the blooming period lower than the rest of the treatment. The response was the opposite in $\mathrm{AO}$ conditions, where the total GDD was higher than the rest of the treatments. However, the total number of accumulated development days between the five different environmental conditions evaluated was similar (Table 3). This result indicated that the GDD parameter is an important tool in order to correct the variations of plant growth related to temperature differences that occur on different days.

In both varieties, the curves that represent the flowering dynamics in different environmental conditions become erratic after the tenth flowering node, that is

Table 3. Period of reproductive development, accumulated days, accumulated growing degree days, and accumulated rain, in each environmental condition of plant growth.

\begin{tabular}{|c|c|c|c|c|}
\hline Environmental Condition & $\begin{array}{l}\text { Reproductive Development } \\
\text { Period }^{1}\end{array}$ & Cumulative Days & $\begin{array}{l}\text { Reproductive Development } \\
\text { Period (CDD) }\end{array}$ & $\begin{array}{l}\text { Cumulative Rain } \\
\qquad(\mathrm{mm})\end{array}$ \\
\hline $\begin{array}{l}\text { Y2: Without cutting } \\
\text { Y2: With cutting } \\
\text { YO: Without cutting }\end{array}$ & $\begin{array}{l}\text { Year } 1997 \\
\text { May } 16 \text { - June } 25 \\
\text { June } 6 \text { - July } 17 \\
\text { July } 1 \text { - August } 11\end{array}$ & $\begin{array}{l}40 \\
41 \\
41\end{array}$ & $\begin{array}{l}454 a \\
491 a \\
621 b\end{array}$ & $\begin{array}{c}74 \\
143 \\
83\end{array}$ \\
\hline $\begin{array}{l}\text { Y0: Without cutting } \\
\text { Y1: With cutting }\end{array}$ & $\begin{array}{l}\text { Year } 1998 \\
\text { June } 26 \text { - August } 7 \\
\text { June } 5 \text { - July } 19\end{array}$ & $\begin{array}{l}42 \\
44\end{array}$ & $\begin{array}{l}583 b \\
550 a\end{array}$ & $\begin{array}{l}73 \\
84\end{array}$ \\
\hline
\end{tabular}

Means with the same letters between lines within each year are not statistically different (P>0.05). A0, A1, A2; sowing year and two years after regrowth.

${ }^{1}$ Period lapsed from the beginning of flowering until seed maturity 
to say, once 300 GDD were reached (approximately $25 \mathrm{~d}$ of reproductive development) counted from the beginning of flowering (Figures $1 \mathrm{a}$ and $\mathrm{b}$ ). This behavior was the consequence of the decrease in the number of primary stems with more than ten flowering nodes in all the environmental conditions evaluated, as shown by Huyghe et al. (2001) who studied vertical (between different flowering nodes along the primary stem) and horizontal (at the same level of the flowering node, but between primary stems) distribution in the production of alfalfa seeds.

The number of flowering nodes by stem varied from $14(\mathrm{~A} 0)$ to 17 (A1 and A2 with and without cutting) for both varieties. The number of stems with more than ten floral nodes was also lower in AO than in the other environmental conditions. The duration of the reproductive development period was calculated based on the sum of GDD. These results deduce that the first ten floral nodes are important in the definition of seed production at the end of 300 GDD, counted from the beginning of flowering. Authors such as Bolaños and Huyghe (2005) previously observed in the European and Magali varieties that during the first $600 \mathrm{GDD}$ of the reproductive period, the accumulation of dry matter was primarily assigned to reproductive organs rather than stems and roots. Considering that in alfalfa the time required to go from "open flower" in an inflorescence to another on the same primary stem was between 24 and 48 hours, as previously demonstrated by Genter et al. (1997), depending on the GDD; and that the seed development model can be measured by GDD from pollination, then it is possible to develop a model that explains alfalfa seed production. Determining flowering dynamics in varieties of broad use in different alfalfa production regions in Mexico would be of great use in order to predict the moment of seed harvesting.

\section{CONCLUSIONS}

The flowering dynamics along the primary alfalfa stem is described as a linear function based on accumulated growing degree days (GDD) during the reproductive period, with basal temperature of $5{ }^{\circ} \mathrm{C}$. The pattern followed by the flowering dynamics (linear relation) does not vary between varieties, but depending on the environmental condition, the necessary GDD varies in order for alfalfa to reach seed maturation and for seed harvesting.

\section{ACKNOWLEDGMENTS}

We thank the technical assistance of J. Jousse and A. Gilly from the INRA (National Institute of Agricultural Research) in France. The primary author also thanks the CONACYT, INIFAP and the SFERE (French Society for the Exportation of Educational Resources) for the financial support.

\section{REFERENCES}

Baldissera, T.C., Frak, E., Carvalho, P.C.F., \& Louarn, G. (2014) Plant development controls leaf area expansion in alfalfa plants competing for light. Annals of Botany 113: 145-157. doi. org/10.1093/aob/mct251

Bolaños-Aguilar, E.D., Huyghe, C., Ecalle, C., Hacquet, J., \& Julier, B. (2002) Efect of cultivar and environment on seed yield in alfalfa. Crop Science 42: 45-50. doi: 10.2135/cropsci2002.4500

Bolaños-Aguilar, E.D., \& Huyghe C. (2005) Crecimiento y distribución de la materia seca entre órganos vegetativos y reproductores en alfalfa. Agricultura Técnica en México. 13: 65-72. https:// www. redalyc.org/articulo.oa?id $=60831107$

Brown, H.E., Moot, D.J., \& Teixeira, E. (2006). Radiation use efficiency and biomass partitioning of lucerne (Medicago sativa) in a temperate climate. European Journal of Agronomy 25: 319327. doi: 10.1016/j.eja.2006.06.008

Daur, I., Sepetoglu, H., \& Sindel B. (2011) Dynamics of faba bean growth and nutrient uptake and their correlation with grain yield. Journal of Plant Nutrition 34: 1360-1371. Doi.org/10.1080/01 904167.2011 .580878

Genter, T., Dens, E., \& Fleury, A. (1997) Influence of photosynthetic restriction due to defoliation at flowering on seed abortion in lucerne (Medicago sativa L.). Journal of Experimental Botany 48: 1815-1823. doi.org/10.1 093/jxb/ 48.10. 1815

Huyghe, C., Julier, B., Bolaños-Aguilar, E.D., \& Ecalle, C. (2001) 3D distribution of seed in alfalfa seed canopy. Pp. 37-40. In: Quality in Lucerne and medics for animal production. Proceedings of the XIV Eucarpia Medicago spp Group Meeting. 12-15 September. I.A.M. Zaragoza, Spain.

Jenni, S., Bourgeois, G., Laurence, H., Roy, G., \& Tremblay, N. (2000) Improving the prediction of processing bean maturity based on the Growing degree day approach. Hortscience 35: 12341237. doi: 10.21273/Hortsci 35.4.611

Jungers, J.M., Brakke, M., Rendahl, A., \& Sheaffer, C.C. (2016) Identifying Base Temperature for Alfalfa Germination: Implications for Frost Seeding. Crop Science 56:2833-2840. doi: 10.2135/ cropsci2016.02.0109

Kakon, S.S., Mian, M.A.K., Saha, R.R., Nasreem, S.S., Naher, Q., \& Hossain, M. (2019) Phenology, growth and pod yield of french bean (Phaseolus vulgaris l.) as influenced by temperature variations under different sowing dates. Bangladesh Agronomy Journal 21: 25-32. doi: 10.3329/baj.v21i2.44489

Khaiti, M., \& Lemaire, G. (1992) Dynamics of shoot and root growth of lucerne after seeding and after cutting. European Journal Agronomy 4: 241-247. doi: doi.org/10.1016/S11610301(14)80076-2

Krishna-Jagadish, S.V., Bahuguna, R.N., Djanaguiraman, M., Gamuyao, R., Vara Prasad, P.V., \& Craufurd, P.Q. (2016) Implications of High Temperature and Elevated $\mathrm{CO}_{2}$ on Flowering Time in 
Plants. Frontiers in Plant Science 7: 913. doi.org: 10.3389/ fpls.2016.00913

Lagunes-Espinoza, L.C., Huyghe, C., Papineau, J., \& Shield, L. (2000) Dry matter and nitrogen accumulation during pod wall development of white lupin genotypes differing in proportion of pod walls. The Journal of Agricultural Science 135: 389-397. doi: $10.1017 /$ S0021859699008278

Lesins, K.A., \& Lesins, I. (1979) Genus Medicago (Leguminosae). A taxogenetic study. ISBN 978-94-009-9634-2. Junk bv Publisher. The Hague. 228 p.

Nico, M., Mantense, A.I., Miralles, D.J., \& Kantolic, A.G. (2016) Soybean fruit development and set at the node level under combined photoperiod and radiation conditions. Journal of Experimenta Botany 67: 365-377 doi: 10.1093/jxb/erv475

Otero, A., \& Castro, M. (2019) Variability of Alfalfa (Medicago sativa L.) Seasonal forage production in the southwest of Uruguay Agrociencia Uruguay 23: 1-11. doi: 10.31285/AGRO.23.1.9

Sanderson, M.A., Karnezos T.P., \& Matches, A.G. (1994) Morphological development of alfalfa as a function of growing degree days. Journal of Production Agriculture 7: 239-242. doi: 10.2134/ jpa1994.0239

SAS Institute (2010) SAS/STAT User's Guide: Version 9.2 SAS Institute, Inc. Cary, North Carolina, USA. 1689 p

Sharrat, B.S., Sheaffer, C.C., \& Baker, D.G. (1989) Base temperature for the application of the growing-degree-day model to field-grown alfalfa. Field Crop Research 21: 95-102. doi. org/10.1016/0378-4290(89)90045-2

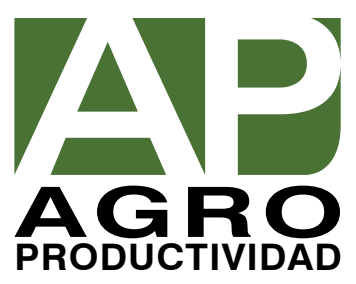

